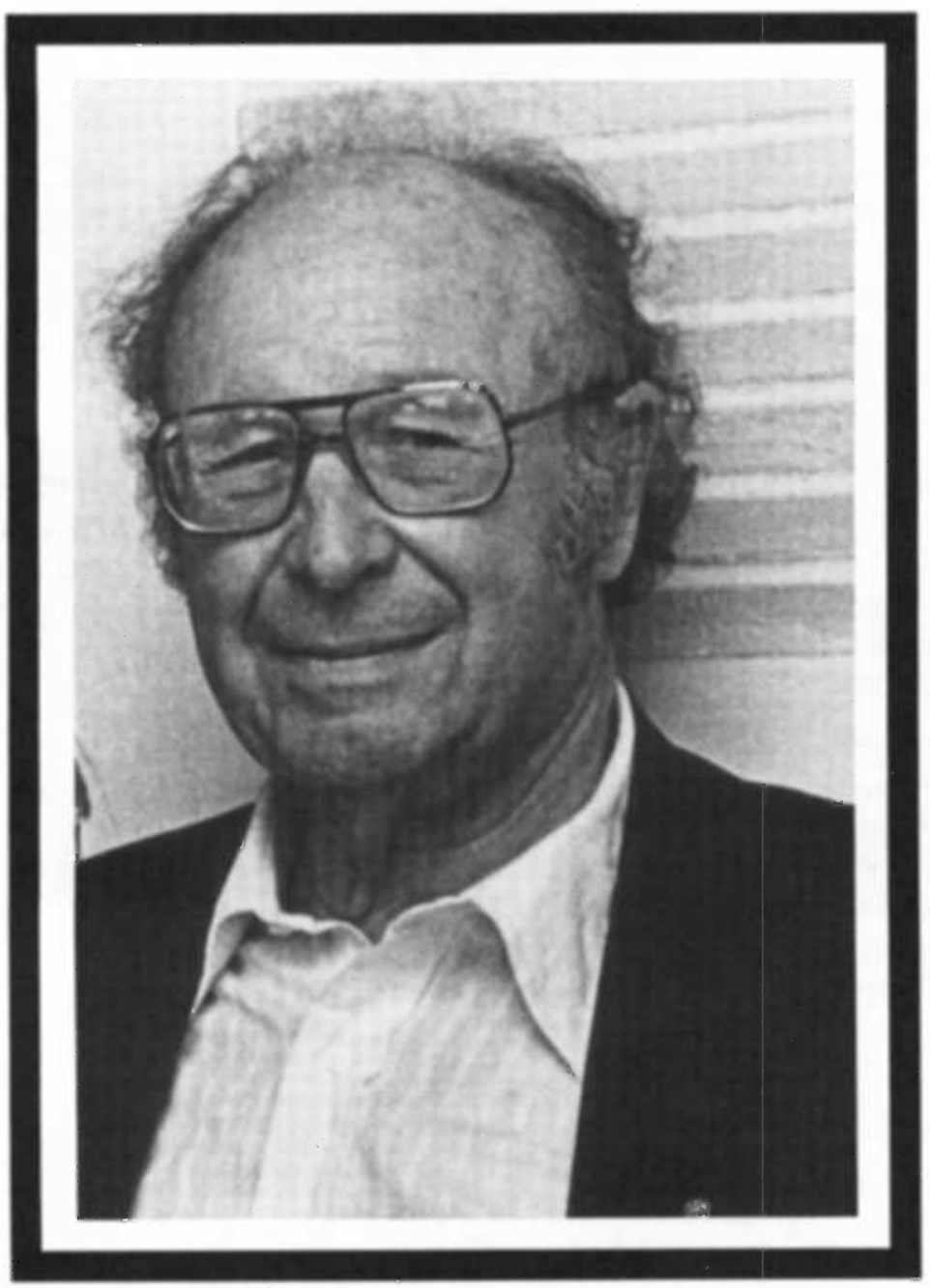

HANS E. SUESS, 1909-1993

Prof. Hans Suess was one of the pioneers of ${ }^{14} \mathrm{C}$ dating, and one of the first to develop the closely related field of ${ }^{14} \mathrm{C}$ geophysics. This was only one facet of a many-sided career, which included important contributions to the shell theory of nuclear structure, to the abundance curve of chemical elements and isotopes, and to nucleosynthesis. These other subjects are treated more fully in another memoir (Meteoritics 28 (1994): 289-290).

The present account is rather personal in nature. I knew Prof. Suess at Chicago early in both our careers, while I was still working with Willard Libby on the development of the method. From 1958 on, we were colleagues and friends at the University of California, San Diego (UCSD).

He came from a remarkable Austrian scientific family; his paternal grandfather and his father were both distinguished geologists. He was trained in physical chemistry, and made his first contributions in that field. After receiving his Ph.D. degree from the University of Vienna, Suess worked at ETH, Zurich, and the University of Hamburg. Harrison Brown, then on the Chicago faculty, 
brought him and his family to the U.S. in the late 1940s. Suess quickly saw the possibilities in Libby's ${ }^{14} \mathrm{C}$ work, and decided to commit himself to this new field.

Libby at that time was receiving many inquiries from persons interested in setting up ${ }^{14} \mathrm{C}$ labs. $\mathrm{He}$ was determined to assist this process, not wanting, as he often said, to be "the Pope of archaeological dating". One of my last tasks in his group was to instruct selected persons in the method by taking them stepwise through our procedures. Several people went through this regime. The others took careful notes of each detail, and at first, stuck closely to Libby's techniques. Suess quickly grasped the principles, but showed boredom when exposed to details. He was already planning his own gas-counting approach.

After a short period at the University of Chicago, he went on to set up his first lab at the U.S. Geological Survey in Washington. Almost at once he began to produce important science. He explored and clarified the chronology of the end of the last ice age. He documented the 20th-century decrease in contemporary ${ }^{14} \mathrm{C}$ values caused by fossil-fuel burning, which I later christened the Suess Effect. I well remember Bill Libby's pleasure at receiving these results; he felt then that the future of the subject was safe.

In 1956, Suess received an offer from Roger Revelle to come and set up a ${ }^{14} \mathrm{C}$ lab at the Scripps Institution of Oceanography, then poised to develop into UCSD. He accepted and moved into a growing group of scientists with related interests, including Revelle himself. The subject of the distribution of ${ }^{14} \mathrm{C}$ among the various reservoirs was beginning to engage attention, and Revelle and Suess published one of three parallel papers in Tellus in 1958 dealing with this issue. It was this paper that first clearly set forth the problem of "global warming" with the man-made increase in atmospheric $\mathrm{CO}_{2}$. However, Suess had already referred to it, in his often somewhat oblique style, earlier on.

In the early years of the La Jolla lab, his work spanned a wide range of interests. With the help of Carl Hubbs, he measured many archaeological samples. He began a pioneering series of measurements of $\mathrm{CO}_{2}$ in surface and deep ocean waters, assisted by George Bien, who became his chief aide over many years. He also continued some work on glacial history.

While his lab continued to publish date lists and otherwise support a broad range of studies, he became increasingly devoted to a series of careful measurements of bristlecone pine tree rings, using material provided by the University of Arizona Tree-Ring Laboratory. This provided a remarkable record of variations in the ${ }^{14} \mathrm{C}$ content of the atmosphere, extending continuously back more than 8000 years. The peak in ${ }^{14} \mathrm{C}$ content in the 17 th century $\mathrm{AD}$, first reported by de Vries, was found to be only one of a series of such events, presumably associated with decreases in sunspots and other measures of solar activity.

At the 12th Nobel Symposium held in Uppsala, Sweden in August 1969, Suess published his first calibration curve extending back to $5300 \mathrm{BC}$. This precipitated the second revolution in ${ }^{14} \mathrm{C}$ dating when Renfrew, using the Suess curve, demonstrated that Celtic astronomers at Stonehenge preceded the Egyptians rather than learning astronomical lore by cultural diffusion from Egypt. This first calibration curve included such earlier excursions christened (by others) "Suess wiggles". Unfortunately, statisticians cast doubts on the existence of the wiggles, leading to a debate concerning smooth $v s$. wiggle calibration curves. Subsequent work by the Groningen Laboratory and an NSF Workshop in Tucson, Arizona (1979) confirmed the validity of a wiggle calibration curve extending back to $8000 \mathrm{BP}$. Further high-precision work has left no doubt concerning the validity of wiggle calibration curves. The original discoveries remain of fundamental significance. The data have been 
used by Sonett and others in the search for understanding of the Sun's behavior on the ${ }^{14} \mathrm{C}$ time scale, and of the causes of the apparent correlations between these variations and the terrestrial climate.

Suess was a member of the National Academy of Science, the Heidelberg Academy of Science, the Austrian Academy of Science, the Max Planck Society, West Germany, and the American Academy of Arts and Sciences. His awards included the Goldschmidt Medal (1974), the Leonard Medal (1977) and the Humboldt Award (1978).

Hans Suess had a rich and varied life, which kept him constantly involved with major scientific and human issues. His intuitive power was remarkable, often outrunning his colleagues' ability to understand him. He was an excellent, though unorthodox, experimentalist. One pictures him always in later years either travelling or on the telephone, until illness overtook him at the end. It was a privilege to have known him.

\section{James R. Arnold}

\section{SELECTED BIBLIOGRAPHY}

Suess, H. E. 1953 Natural radiocarbon and the rate of exchange of carbon dioxide between the atmosphere and the sea. In Aldrich, L. T., ed., Proceedings of Conference on Nuclear Processes in Geological Settings. National Research Council, Commission on Nuclear Science 1: 52-56.

1954a Natural radiocarbon measurements by acetylene counting. Science 120: 5-7.

1954b U.S. Geological Survey radiocarbon dates I. Science 120: 467-473.

1955a Absolute chronology of the last glaciation. Science 123: 355-357.

$1955 b$ Radiocarbon concentration in modern wood. Science 122: 415-417.

1956 Grundlagen und Ergebnisse der Radiokohlenstoff-Datierung. Angewandte Chemie 68: 540-546.

1958 Radioactivity of the atmosphere and hydrosphere. Annual Review of Nuclear Science 8: 243256.

1961a Die Methode der Radiokohlenstoffdatierung und ihre Bedeutung für prähistorische Forschung. Bericht V. Kongress für Vor-und Fruhgeschichte. Berlin, Verlag Gebr. Mann: 798-794.

$1961 \mathrm{~b}$ Secular changes in the concentration of atmospheric radiocarbon. National Academy of Science, National Research Council Publication 845 (33): 90 94.

1965 Secular variations in the cosmic ray-produced carbon-14 in the atmosphere and their interpretations. Journal of Geophysical Research 70: 5937-5952. 1966 Some chemical aspects of the evolution of the terrestrial atmosphere. Tellus 28: 207-211.

1967a Bristlecone pine calibration of the radiocarbon time scale from 4100 B.C. to 1500 B.C. In Proceedings of the Monaco Symposium on Radioactive Dating and Methods of Low-Level Counting. Vienna, IAEA: 143-151. 1967b Zur Chronologie des alter Agypten. Zeitschrift für Physik 202:1-7.

1968 Climatic changes, solar activity, and the cosmic ray production rate of radiocarbon. Meteorological Monographs 8(30): 146-150.

1969a Die Eichung der Radiokarbonuhr. Bild der Wissenschaft 2:121-127.

1969b Tritium geophysics as an international research project. Science 163:1405-1410.

1970a Bristlecone pine calibration of the radiocarbon time scale 5300 B.C. to the present. In Olsson, I., ed., Radiocarbon Variations and Absolute Chronology, Proceedings of the 12th Nobel Symposium. Stockholm, Almqvist \& Wicksell: 303-313.

$1970 \mathrm{~b}$ Climate and radiocarbon during the Middle Ages. In R. Berger, ed., Scientific Methods in Medieval Archaeology. Berkeley and Los Angeles, California, University of California Press: 159-166.

1970c The three causes of the secular carbon-14 fluctuations, their amplitudes and time constants. In Olsson, I., ed., Radiocarbon Variations and Absolute Chronology, Proceedings of the 12th Nobel Symposium. Stockholm, Almqvist \& Wicksell: 595-605.

$1970 \mathrm{~d}$ Transfer of carbon-14 and tritium from the atmosphere into the ocean. In Proceedings of the CACR Symposium on Atmospheric Trace Constituents and Atmospheric Cirulation. Journal of Geophysical Research 75:2363-2364.

1971 Climatic changes and the atmospheric radiocarbon level. Paleogeography, Paleoclimatology, Paleoecology 10: 199-202.

1973a Natural radiocarbon. Endeavour 32: 34-38.

$1973 \mathrm{~b}$ Natural radiocarbon evidence bearing on climatic changes. In Proceedings of the Paleoclimatology Conference. Gif-sur-Yvette, France.

1976 The calibration curve for radiocarbon dates. Antiquity 50: 61-63. 
Suess, H. E. 1978a Absolute radiocarbon dating by lowaltitude European tree-ring calibration (a reply). $\mathrm{Na}$ ture 272: 649.

$1978 \mathrm{~b} \mathrm{La}$ Jolla measurements of radiocarbon in tree-ring dated wood. Radiocarbon 20(1): 1-18.

1979a Were the Allerød and Twocreekan substages contemporaneous? In Berger, R. and Suess, H. E., eds., Radiocarbon Dating, Proceedings of the 9th International ${ }^{14} \mathrm{C}$ Conference. Berkeley/Los Angeles, University of California Press: 76-82.

$1979 \mathrm{~b}$ The carbon-14 level during the fourth and second half of the fifth millennium $B C$ and the carbon14 calibration curve. In Berger, R. and Suess, H. E., eds., Radiocarbon Dating, Proceedings of the 9th International ${ }^{14} \mathrm{C}$ Conference. Berkeley/Los Angeles, University of California Press: 538-544.

1979c A calibration table for conventional radiocarbon dates. In Berger, R. and Suess, H. E., eds. Radiocarbon Dating, Proceedings of the 9th International ${ }^{14} \mathrm{C}$ Conference. Berkeley/Los Angeles, University of California Press: 777-784.

1979 c Ist die Sonnenaktivität für Klimaschwankungen verantwortlich? Umschau 79.

1979d The solar wind during the Maunder minimum. Planetary Space Science 27:1001-1013.

1980a Radiocarbon geophysics. Endeavour 4:113 117.

$1980 \mathrm{~b}$ The radiocarbon record in tree rings of the last 8000 years. In Stuiver, M., and Kra, R. S., eds., Proceedings of the 10th International ${ }^{14} \mathrm{C}$ Conference. Radiocarbon 22(2): 200-209.

1986 Secular variations of cosmogenic ${ }^{14} \mathrm{C}$ on Earth: Their discovery and interpretation. In Stuiver, M. and Kra, R. S., eds., Proceedings of the 12th International ${ }^{14} \mathrm{C}$ Conference. Radiocarbon 28(2A): 259-265.

1987 Chemistry of the Solar System. New York, Wiley Interscience: $143 \mathrm{p}$

1990 A comparison of high-precision calibrations of the radiocarbon time scale by three different laboratories. In Mook, W. G. and Waterbolk, H. T., eds., Proceedings of the 2nd International Symposium ${ }^{14} \mathrm{C}$ and Archaeology. Strasbourg, PACT 29: 51-54.

1992 The early radiocarbon years: Personal reflections. In Taylor, R. E., Long, A. and Kra, R. S., eds., Radiocarbon After Four Decades: An Interdisciplinary Perspective. New York, Springer-Verlag: 11-16.

Suess, H. E. and Becker, B. 1977 Der Radiocarbongehalt von Jahrringproben aus postglazialen Eichenstämmen Mitteleuropas. In Frenzel, B., ed., Dendrochronologie und Postglaziale Klimaschwankungen in Europa. Erdwissenschaftliche Forschung 13: 156-170.

Suess, H. E. and Goldberg, E. 1971 Comments on "Abyssal Carbon and Radiocarbon in the Pacific" by Craig, H. Journal of Geophysical Research 76(21): 5131-5132.

Suess, H. E. and Linick, T. W. 1990 The ${ }^{14} \mathrm{C}$ record in bristlecone pine wood of the past 8000 years based on the dendrochronology of the late C. W. Ferguson. Philosophical Transactions of the Royal Society [London] A330: 403-412.

Suess, H. E. and Strahm, C. 1970 The Neolithic of Auvenier: Calibrated radiocarbon dates. Antiquity 44: 9195.

Suess, H. E. and Wänke, H. 1965 On the possibility of a helium flux through the ocean floor. Progress in Oceanography 3: 347-353.

Bainbridge, A. E., Sandoval, P. and Suess, H. E. 1961 Natural tritium measurements by ethane counting. Science 134: 552-553.

Bainbridge, A. E., Suess, H. E. and Friedman, I. 1961 Isotopic composition of atmospheric hydrogen and methane. Nature 192(4803): 648-649.

Berger, R., Jackson, T. B., Michael, R. and Suess, H. E. 1987 Radiocarbon content of tropospheric $\mathrm{CO}_{2}$ at China Lake, California 1977-1983. Radiocarbon 29 (1):18-23.

Berger, R. and Suess, H. E., eds. 1979 Radiocarbon Dating, Proceedings of the 9th International ${ }^{14} \mathrm{C}$ Conference. Berkeley/Los Angeles, University of California Press.

Bien, G. S., Rakestraw, N. W. and Suess, H. E. 1956 U.S. Geological Survey radiocarbon dates III. Science 123: 442-448.

1960 Radiocarbon concentration in Pacific Ocean water. Tellus 12(4): 436-443.

1963 Radiocarbon dating of deep water of the $\mathrm{Pa}$ cific and Indian Oceans. Bulletin of the Institute of Oceanography, Monaco 61: 159-173.

1965 Radiocarbon in the Pacific and Indian oceans and its relation to deep water movements. Limnology and Oceanography 10(supplement): R25-37.

Bien, G. S. and Suess, H. E. 1959 Increase of $\mathrm{C}^{14}$ in the atmosphere from artificial sources measured in a $\mathrm{Cal}$ ifornia tree. Zeitschrift für Physik 154: 172-174.

1967 Transfer and exchange of ${ }^{14} \mathrm{C}$ between the atmosphere and the surface water of the Pacific Ocean. In Radioactive Dating and Methods of Low Level Counting. Vienna, IAEA: 105-115.

Bruns, M., Rhein, M., Linick, T. W. and Suess, H. E. 1983 The atmospheric ${ }^{14} \mathrm{C}$ level in the 7th millennium BC. In Mook, W. G. and Waterbolk, H. T., eds., Proceedings of the International Symposium ${ }^{14} \mathrm{C}$ and $\mathrm{Ar}$ chaeology. Strasbourg, PACT 8: 511-516.

Cain, W. F. and Suess, H. E. 1976 Carbon-14 in tree rings. Journal of Geophysical Research 81(21): 36883694.

Dockins, K. O., Bainbridge, A. E., Houtermans, J. C. and Suess, H. E. 1967 Tritium in the mixed layer of the North Pacific Ocean. In Proceedings of the Monaco Symposium on Radioactive Dating and Methods of Lowlevel Counting. Vienna, IAEA: 129-141.

Druffel, E. M. and Suess, H. E. 1983 On the radiocarbon record in banded corals: Exchange parameters and net transport of ${ }^{14} \mathrm{CO}_{2}$ between atmosphere and surface 
ocean. Journal of Geophysical Research 88(C2): 1271-1280.

Ferguson, C. W., Gimbutas, M. and Suess, H. E. 1976 Historical dates for the Neolithic sites of southeast Europe. Science 191: 1170-1172.

Ferguson, C. W., Huber, B. and Suess, H. E. 1966 Determination of the age of Swiss Lake dwellings as an example of dendrochronologically calibrated radiocarbon dating. Zeitschrift für Naturforschung 21a: 11731177.

Houtermans, J. C., Oeschger, H. and Suess, H. E. 1973 Reservoir models and production rate variations of natural radiocarbon. Journal of Geophysical Research 78: 1898-1908.

Houtermans, J. C., Suess, H. E. and Munk, W. 1967 The effect of industrial fuel combustion on the carbon-14 level of atmospheric $\mathrm{CO}_{2}$. In Proceedings of the Monaco Symposium on Radioactive Dating Methods of Low-Level Counting. Vienna, IAEA: 57-58.

Hubbs, C. L., Bien, G. S. and Suess, H. E. 1960 La Jolla natural radiocarbon measurements. American Journal of Science Radiocarbon Supplement 2: 197-223.

1962 La Jolla natural radiocarbon measurements II. Radiocarbon 4: 204-238.

1963 La Jolla natural radiocarbon measurements III. Radiocarbon 5: 254-272.

$1965 \mathrm{La}$ Jolla natural radiocarbon measurements IV. Radiocarbon 7: 66-117.

König, H., Wänke, H., Bien, G. S., Rakestraw, N. W. and Suess, H. E. 1964 Helium, neon and argon in the oceans. Deep Sea Research 11: 243-247.

Kruse, H. H., Linick, T. W., Suess, H. E. and Becker, B. 1980 Computer-matched radiocarbon dates of floating tree-ring series. In Stuiver, M., and Kra, R. S., eds., Proceedings of the 10 th International ${ }^{14} \mathrm{C}$ Conference. Radiocarbon 22 (2): 260-266.

Lal, D. and Suess, H. E. 1968 The radioactivity of the atmosphere and hydrosphere. Annual Review of $\mathrm{Nu}$ clear Science 18:407-434.

Linick, T. W. and Suess, H. E. 1972 Bomb produced radiocarbon in the surface water of the Pacific Ocean. In Rafter, T. A. and Grant-Taylor, T. E., eds., Proceedings of the 8th International ${ }^{14} \mathrm{C}$ Conference. Welling ton, New Zealand, Royal Society of New Zealand: C87-C93.

Linick, T. W., Suess, H. E. and Becker, B. 1985 La Jolla measurements of radiocarbon in south German oak tree-ring chronologies. Radiocarbon 27(1): 20-32.

Lodge, J. P., Bien, G. S. and Suess, H. E. 1960 The $C^{14}$ content of urban airborne particulate matter. International Journal for Air Pollution 2: 309-312.

MacKie, E., Collins, J., Ewer, D. W., Smith, A., Suess, H. A. and Renfrew, C. 1971 Thoughts on radiocarbon dating. Antiquity 45: 197-204.

Michel, R. L. and Suess, H. E. 1975 Bomb tritium in the Pacific. Journal of Geophysical Research 80: 41394152.

1978 Tritium in the Caspian Sea. Earth and Planetary Science Letters 39: 309-312.

Neftel, A., Oeschger, H. and Suess, H. E. 1981 Secular non-random variations of cosmogenic carbon-14 in the terrestrial atmosphere. Earth and Planetary Science Letters 56: 127-147.

Revelle, R. and Suess, H. E. 1957 Carbon dioxide exchange between atmosphere and ocean and the question of an increase of atmospheric $\mathrm{CO}_{2}$ during the past decades. Tellus 9: 18-27.

1962 Interchange of properties between the sea and atmosphere. In Hill, M. N., ed., The Sea: Ideas and Observations on Progress in the Study of the Seas. London, Interscience Publishers.

Rubin, M. and Suess, H. E. U.S. Geological Survey radiocarbon dates II. Science 121: 481-488.

Sonett, C. P. and Suess, H. E. 1984 Correlation of bristlecone pine ring widths with atmospheric ${ }^{14} \mathrm{C}$ variations: A climate-Sun relation. Nature 307(5947): 141-143.

Stuiver, M. and Suess, H. E. 1966 On the relationship between radiocarbon dates and true sample ages. Radiocarbon 8: 534-540. 